\title{
The Effect of Using Flipped Classroom Model on Libyan University Students' English Learning
}

\author{
Mustafa Salem Braiek ${ }^{1}$ \\ Faculty of Arts \\ Misurata University
}

\author{
Abdulhamid Elmurabet Onaiba \\ Faculty of Education \\ Misurata University
}

https://doi.org/10.36602/faj.2018.n12.11

\begin{abstract}
This study aimed at investigating the effectiveness of using flipped classroom model on learning English as a foreign language and students' attitudes towards flipped classroom. The sample of study consisted of 31 students at Faculty of Arts, Misurata University. The participants were divided into two groups: 16 students for the experimental group and 15 students for the control group. The data collection tools used in this study were an EFL (English as a Foreign Language) test and a questionnaire to explore students' attitudes towards flipped classroom. Participants in both groups were pre-tested using the EFL test before the experiment. Then, the experimental group was taught using flipped classroom strategy while the control group was taught using the traditional teaching method. After the experiment, students in both groups were post-tested using the EFL test while the questionnaire was administered to the students of the experimental group only. The results of the study showed that applying the strategy of the flipped classroom had a significant effect in increasing the students' performances in learning English. The questionnaire responses showed positive attitudes regarding the use of flipped teaching.
\end{abstract}

Key words: flipped classroom, EFL, students' attitudes, traditional teaching 


\section{ملغص الدراسة}

$$
\begin{aligned}
& \text { تمدف هذه الدراسة إلى التحقق من فاعلية استخدام نموذج الفصل المعكوس في تعلم اللغة الإنجليزية كلغة أجنبية، ومواقف } \\
& \text { الطلاب بتحاه هذه الطريقة. تكونت عينة الدراسة من } 31 \text { طالب في كلية الآداب، جامعة مصرات، تم تقسيم المشاركين } \\
& \text { إلى مجموعتين: } 16 \text { طالبًا للمجموعة التجريبية و } 15 \text { طالبًا للمجموعة الضابطة. كانت أدوات جمع البيانات المستخدمة } \\
& \text { في هذه الدراسة اختبار اللغة الإنجليزية (الإنجليزية كلغة أجنبية) واستبيان لاستكشاف مواقف الطلاب نهو الفصول } \\
& \text { المعكوسة. تم اختبار المشاركين في كلا المجموعتين قبليا باستخدام اختبار اللغة الإنجليزية لتحديد مستوى الطلاب في } \\
& \text { المجموعتين قبل التجربة وضمان تساويه. بعد ذلك، تم تدريس المجموعة التجريبية باستخدام نموذج الفصل المعكوس بينما } \\
& \text { تم تدريس المجموعة الضابطة باستخدام طريقة التدريس التقليدية. بعد التجربة، تم اختبار الطلاب في كلا المجموعتين } \\
& \text { بعديا باستخدام اختبار اللغة الإنجليزية. بينما تم توزيع الاستبيان على طلاب المجموعة التجريبية فقط ـ أظهرت نتائج } \\
& \text { الدراسة أن تطبيق استراتيجية الفصل المعكوس كان لما تأثير كبير في زيادة أداء الطلاب في تعلم اللغة الإنجليزية. كما } \\
& \text { أظهرت نتائج الاستبيان مواقف إيجابية بحاه استخدام طريقة التدريس المعكوس. }
\end{aligned}
$$

\section{INTRODUCTION}

The twenty-first century has witnessed a huge progress and development of different types of technology in different fields, one of which is language education. Students today are comfortable with electronic devices and keen on social contexts and collaborative activities. Educators work hard to find how to integrate this technology to be influencing on the educational process to enhance collaborative learning and to be utilized as a tool for redesign learning and instructional systems (Karimi, \& Hamzavi, 2017). Abukhattala (2016) and Basal (2015) add that the integration of technology in the process of teaching today results a successful teaching and learning of languages.

Flipped learning is considered to be one of the new active learning approaches that incorporate technology into classrooms to create better learning opportunities for students and to offer motivating classroom atmosphere (Basal, 2015). Flipped learning focuses on switching in-class instruction time with at-home practicing time using technology, especially videos (El-Bassuony, 2016). According to Obari \& Lambacher, (2015) Flipped Classroom Model is a distinctive educational environment, which is quickly growing in popularity among educators worldwide. It is a pedagogical model in which classroom lectures and homework elements are reversed. In a flipped classroom, students learn the course lectures (i.e. through online or recorded videos, course materials, etc.) before they come to class, and spend most of the classroom time in interactive discussions and workshops asking and answering questions (ibid). It inverts traditional teaching, that is, the instruction is delivered outside of the class while homework is done in the classroom (Du, Fu \& Wang, 2014). 
Flipped classroom saves greater amounts of time for teachers tutoring their students instead of lecturing them (Wallace, 2014).

It seemed that the strategy of flipped classroom had not yet been examined in the Libyan context. Thus, the current study is designed to investigate the effectiveness of implementing the flipped classroom model as an alternative strategy of traditional English teaching methods used in teaching English in Libyan higher education to produce good outcomes of learners.

\subsection{Statement of the Problem}

Many studies indicate that Libyan EFL students do not have the opportunity to practice language skills or to engage in English language use outside of the classroom because of the lack of communicative competence (Elabbar, 2011, Khalid, 2017, Sawani, 2009, Reza et al., 2007). One of the reasons behind this lack of meaningful interaction is ascribed to the traditional English teaching methods applied in Libyan schools and universities (ibid). Orafi and Borg, (2009) state that Libyan teachers use traditional teaching methods because they believe these methods are useful and beneficial for students. Also, it is because of that these methods are easy to use and do not require much effort, i.e., Grammar Translation Method. Farah (2014) adds that lecturers use traditional teaching methods because they are influenced by their own experience as students that they tend to repeat the role of their former teacher. Elabbar (2011) points out that a lot of Libyan lecturers are affected by learning beliefs of traditional Libyan classroom in which a teacher is the authority in the classroom and has more control over students' interaction and participation and he is the only source of knowledge (ibid). According to Elabbar (2011), many Libyan teachers of English still believe that the most important teacher's role is to explain segments of grammatical structures to students and translate rules into Arabic. Classes are teacher-centred and the students are passive recipients. The interaction in the classroom is teacher to students and students are not encouraged. So the outputs of these traditional methods are students who are unable to communicate effectively and properly in real life (Sawani, 2009). This may be one of the most problematic aspects that resulted of teacher-centered methods. Elabbar (2011) and Sawani (2009) point out that Libyan teachers avoid using Communicative Language Teaching Approach because it does not provide enough guidance to the teacher and because lecturers and learners are affected by the silent culture of learning, that may restrict the use of this approach.

Furthermore, literature in the Libyan context shows that students pay most of their attention to develop language accuracy in exams at the expense of the communicative value of language learning (Aloreibi \& Carey, 2016). Aloreibi and Carey (2016) state that EFL college students in many of the Libyan universities have low English proficiency. Rajendran (2010) adds that Libyan "university students fail to understand the meaning of even the commonly used English words like 'post office', 'money', 'street" (p 64).

As a teacher of English for several years, the current researcher has realized that most students are not competent and their deficiency is obvious in using language in real life situations. In this regard, students tend to transfer their L1 norms of speaking into L2. Therefore, teachers need to change their traditional way of teaching, and keep up the pace with developments and follow the new trends of teaching which get benefit from the current modern technologies and the internet. 


\subsection{Research Questions}

The study grows out of the idea that the teaching of English to Libyan college students could be improved and led to positive effects if the traditional teaching of English (teachercentered) is converted into flipped teaching (student-centered). The main research questions of this study are:

- Is it possible to apply the flipped classroom model to the Libyan college students?

- Does the flipped classroom model have any statistically significant effect on Libyan college students' achievement in learning English?

- What are the Libyan college students' perceptions toward implementing the flipped classroom model of instruction?

\subsection{Research Objectives}

The proposed study intends to examine the impact of using flipped classroom model on Libyan students in learning English at the university stage. It aims to determine whether the flipped classroom teaching model is applicable and more effective than traditional English teaching methods applied in Libyan universities. The study also attempts to explore the extent to which the flipped classroom can help students to be autonomous and moves toward a learner-centered class and helps to facilitate learning.

\section{Literature Review}

According to many scholars i.e. (Lo \& Hew, 2017, El-Bassuony 2016, Obari \& Lambacher, 2015) one strategy for incorporating technology like videos and video lectures is the flipped classroom. El-Bassuony (2016, p. 76) states that "Flipped learning (FL) is considered to be one of the active learning approaches that focuses on switching in-class instruction time with at-home practicing time using technology, especially videos." Milman (2012, p. 85) explains the concept of flipped classroom as:

The idea is that rather than taking up valuable class time for an instructor to introduce a concept (often via lecture), the instructor can create a video lecture, screencast, or vodcast that teaches students the concept, freeing up valuable class time for more engaging (and often collaborative) activities typically facilitated by the instructor.

The use of flipped classrooms model as an instructional technique is encouraged by many research studies' findings. The studies confirm the effectiveness of this strategy of teaching, which meets the needs of the new generation of students; besides, it has significant positive impact on the process of learning.

\subsection{Flipped Classroom Related Studies}

Recently, flipped classroom model has become a popular pedagogy in a lot of educational institutes all over the world and the impact of this strategy has been explored in many studies. The following paragraphs present a short summary of some related studies.

In a study carried out by Ahmad (2016) aimed to investigate the flipped classroom model impact on listening comprehension of Egyptian EFL students. Participants were 34 EFL 
college students. The researcher adopted one-group pre-posttest design. The pretest on listening comprehension was applied before the experiment and the posttest after it. The results indicated that the flipped method had a significant impact on listening comprehension.

Another study conducted by Ahmed (2016) to investigate the impact of flipped classroom on EFL writing skill and students' attitude towards the flipped teaching. The participants of this study were 60 Saudi students at Qassim University, divided into 30 students as an experimental group and 30 students as a control group. The data collection tools were an EFL writing test and a questionnaire. The experimental group was taught by flipped classroom model while the control group was taught traditionally. At the end, both groups were posttested. Results indicated that the experimental group performed better than the control group in the post-test. In addition, the questionnaire results were in favor of the flipped method. This positive result can be attributed to using flipping.

Also, Karimi and Hamzavi, (2017) carried out a study to explore the impact of the flipped classroom model on reading comprehension ability of EFL students as well as their attitudes regarding the flipped method. 50 Iranian EFL students who were studied at a private language institute in Isfahan were selected and divided into an experimental group and a control group. Reading comprehension pre-test was made and given to the participants of the both groups. Flipped model of instruction was applied in teaching the experimental group, while the control group taught by traditional model. Finally, reading comprehension post-test was given to the two groups. Also, a questionnaire was created to examine the students' attitudes. The results showed that the flipped model had a significant positive impact on students' reading comprehension ability. The study also revealed that participants had positive attitude towards flipped strategy.

Moreover, Al-Harbi and Alshumaimeri, (2016) carried out a study to test the effect of the flipped classroom strategy in teaching English grammar on performances, perceptions, and attitudes of Saudi secondary school students. Students were assigned into two groups; experimental group (20) and control group (23). The experimental group students asked to watch selected videos, based on their textbook, was uploaded on Edmodo site prior lessons. Whereas the control group students received traditional teaching. The results of the post-test indicated that applying the strategy of the flipped classroom had a significant effect in increasing the students' grammar performances. The questionnaire responses and interviews showed positive attitudes regarding the use of flipped teaching.

Furthermore, Basal, A. (2015) conducted a study to explore Turkish English language teachers' perceptions of flipped classrooms as well as the implementation of this model into an English class. Participants of this study were 47 prospective English teachers. Basal used Qualitative research design for the study. Open-ended questions were used for collecting data. It was found that teachers showed positive perceptions toward using the flipped classroom. The study also concluded many benefits of applying the flipped classroom in ELT context in terms of saving of class time, learning at one's own pace and students' participation in the class. The study recommended applying the flipped method in departments and contexts.

Having reviewed the pertinent literature, it can be concluded that the flipped classroom model plays a significant and effective role in increasing learners' proficiency levels and 
performance in various areas of ELT. Hung (2015) states that English classes implemented by flipped instructional strategy can improve the academic performance of students in general. However, being this teaching strategy a relatively new trend, there seems a lack of research applied and measured the effects of such a model in the Libyan education context. In this vein, the objective of the current study is to determine whether the flipped classroom model is applicable and effective for Libyan college students. Moreover, it is considered as a contribution to the literature in the Libyan ELT context.

\section{Methodology}

The study adapted the quasi-experimental design to examine the effects of the flipped classroom model on EFL students.

\subsection{Participants}

The participants involved in this study were 31 Libyan college students (6 males and 25 females) majoring Italian and French language departments at the faculty of Arts, Misurata University. All of them are undergraduate students whose ages range from 18 to 23 they are from first to the eighth semesters who have to study English as a core subject. The participants were in two groups; experimental 16 and control 15.

\subsection{Data Collection}

\subsubsection{Tests}

\section{Placement Test}

A placement test consisted of 40 multiple choice items was designed by the researcher (See Appendix A). This test was used to ensure that the both groups (experimental - control) had a similar level of language proficiency.

\section{Post Test}

The researcher designed a test composed of 11 comprehension, fill in the gabs, matching and multiple-choice questions (40 Marks) (See Appendix B) to determine whether there was an impact of the flipped classroom strategy on students' performance in English. The post test was administered to both groups after the experiment.

\subsubsection{Questionnaire}

The other tool was a questionnaire for experimental group students, who taught by flipped classroom strategy, to measure students' attitude towards flipping classroom strategy. The questionnaire consisted of 15 close-ended items, which were scored using a 5-point Likert scale (strongly agree - agree - neutral - disagree - strongly disagree) (See Appendix C).

\subsection{Procedure}

Participants were selected randomly to be two groups; a control group and an experimental group. There were 15 students in the control group and 16 in the experimental group. Both groups were taught by the same teacher and the same syllabus. Both groups were 
tested (placement test) before applying the study and another achievement test after it. The placement test was administered to measure whether the students' language proficiency level is similar.

Flipped classroom model was applied to teach English to the experimental group by selecting video lectures and online material on topics corresponding to the prescribed syllabus. The videos were selected from YouTube website and checked to be appropriate for students' level and to be watched outside the classroom prior the class so that the students could watch them on their own time. Google Classroom was created as platform for the experimental group where instructions, the videos and other materials were uploaded on and to be used as a channel of communication between the students and the teacher. On Google Classroom students were able to write their comments about the videos and post their questions to the teacher. At the beginning of each class the videos were discussed with the students to let the teacher know whether all students had watched these videos or not. During the class any difficult or misunderstood points were answered by the teacher. After that, a collaborative activity or a game was assigned to students to do individually, in pairs, or in groups. However, the control group was taught by using traditional lecturing teaching. That was, the teacher explained everything about the lesson during the class time and the students were asked to do the exercises at home.

Both groups studied the same English elementary syllabus, mostly grammar. The study lasted seven weeks, one class per week. After the treatment, the experimental group and the control group students were post-tested to determine whether there was any statistically significant effect between the mean scores of the two groups. As well as a questionnaire was given to students of the experimental group to explore their opinions towards applying the flipped classroom model in EFL classrooms.

\section{Results}

The scores of the placement test and the post-test were analyzed by means of SPSS software. To compare between the results of the experimental and control groups the Independent Sample T-test was used. The results of the questionnaire were also analyzed quantitatively by SPSS program.

\subsection{Results of the Placement-test}

The results of the placement test showed no significant differences between the two groups concerning their levels of English. (See Table1).

Table 1 Independent Samples Test (Placement-Test)

\begin{tabular}{|c|c|c|c|c|c|}
\hline \multirow{2}{*}{ Groups } & \multicolumn{5}{|c|}{ Std. } \\
\hline & $\mathrm{N}$ & Mean & Deviation & $\mathrm{t}$ & Sig. \\
\hline \multirow{2}{*}{$\begin{array}{c}\text { Experimental } \\
\text { Control }\end{array}$} & 16 & 14.1875 & 5.49204 & \multirow{2}{*}{.364} & \multirow{2}{*}{.718} \\
\hline & 15 & 14.9333 & 5.90964 & & \\
\hline
\end{tabular}

The independent sample t-test showed that there was no significant difference between the experimental group $(\mathrm{M}=14.1875, \mathrm{SD}=5.49204)$ and the control group $(\mathrm{M}=14.9333, \mathrm{SD}=$ 5.90964). 


\subsection{Results of the Post-test}

The Independent Sample T-test indicates that there was a statistically difference between the post-test scores, for the control group $(\mathrm{M}=13.4667, \mathrm{SD}=4.80872)$ and the experimental group $(\mathrm{M}=20.9375, \mathrm{SD}=3.71427) . \mathrm{t}(4.859)$. (See tables 3, 4). (See tables 2, 3)

Table 2 Group Statistics

\begin{tabular}{cccccc}
\hline & Groups & $\mathrm{N}$ & Mean & $\begin{array}{c}\text { Std. } \\
\text { Deviation }\end{array}$ & $\begin{array}{c}\text { Std. Error } \\
\text { Mean }\end{array}$ \\
\hline Score & $\begin{array}{c}\text { Experimental } \\
\text { Group }\end{array}$ & 16 & $\begin{array}{c}20.937 \\
5\end{array}$ & 3.71427 & .92857 \\
\cline { 2 - 6 } & Control Group & 15 & $\begin{array}{c}13.466 \\
7\end{array}$ & 4.80872 & 1.24161 \\
\hline
\end{tabular}

Table 3 Independent Samples Test (Post-Test)

\begin{tabular}{cccccc}
\hline \multirow{2}{*}{$\mathrm{t}$} & df & P-value & \multirow{2}{*}{$\begin{array}{c}\text { Mean } \\
\text { Differences }\end{array}$} & \multicolumn{2}{c}{$\begin{array}{c}95 \% \text { Confidence Interval of } \\
\text { the Difference }\end{array}$} \\
\cline { 5 - 6 } & & & & Lower & Upper \\
\hline 4.859 & 29 & 0.000 & 7.47083 & 4.32648 & 10.61518 \\
\hline
\end{tabular}

\subsection{Questionnaire Results}

The questionnaire was administered to the 16 students of the experimental group after the post-test. The responses of the students were analyzed by the SPSS software, using descriptive statistics to identify frequencies of responses on the Likert scale. Results showed that the opinions and attitudes of experimental group students were positive toward the strategy of the flipped classroom.

The first three items of the questionnaire asked participants whether they enjoy learning English and feel comfortable in English lessons and active by using watching videos in the flipped classes. Students' responses indicated that they agreed that the flipped classroom was more enjoyable learning experience and made them active and comfort (mode=4). (See tables 4, 5, 6)

Table 4 Statement 1. I feel comfortable in English language lessons

\begin{tabular}{cccccc}
\hline & & & Valid & Cumulative \\
Valid & Disagree & 1 & 6.3 & 6.3 & 6.3 \\
& Neutral & 3 & 18.8 & 18.8 & 25.0 \\
& Agree & 7 & 43.8 & 43.8 & 68.8 \\
& strongly & 5 & 31.3 & 31.3 & 100.0 \\
& agree & 16 & 100.0 & 100.0 & \\
\hline
\end{tabular}

Table 5 Statement 2. Teaching English by using Flipped Classroom strategy gives rise to activity

\begin{tabular}{cccccc}
\hline & & Frequency & Percent & Valid Percent Cumulative Percent \\
\hline \multirow{7}{*}{ Valid } & neutral & 4 & 25.0 & 25.0 & 25.0 \\
\cline { 2 - 6 } & Agree & 8 & 50.0 & 50.0 & 75.0 \\
\cline { 2 - 6 } & strongly agree & 4 & 25.0 & 25.0 & 100.0 \\
\cline { 2 - 6 } & Total & 16 & 100.0 & 100.0 & \\
\hline
\end{tabular}


Table 6 Statement 3. I enjoy learning English when the lesson is presented as a video

\begin{tabular}{llllll}
\hline \multirow{2}{*}{ Valid } & Frequency & Percent & \multicolumn{2}{c}{ Valid Percent Cumulative Percent } \\
\cline { 2 - 6 } & disagree & 3 & 18.8 & 18.8 & 18.8 \\
\cline { 2 - 6 } Neutral & 2 & 12.5 & 12.5 & 31.3 \\
\cline { 2 - 6 } & Agree & 9 & 56.3 & 56.3 & 87.5 \\
\cline { 2 - 6 } & strongly agree 2 & 12.5 & 12.5 & 100.0 \\
\cline { 2 - 6 } & Total & 16 & 100.0 & 100.0 & \\
\hline
\end{tabular}

In the fourth and fifth statements students were asked whether Pre-viewing lessons in the flipped classroom helped them understand subjects well and made it easier to answer exercises. Results showed that students agreed and strongly agreed with a percentage of $(43.8 \%)$ for both in favor of the fourth statement (mode=4), and $(68.8 \%)$ agreed in the fifth statement (mode $=4)$. This result indicates that the flipped classroom method facilitated and benefited students' learning of English. (See tables 7, 8)

Table 7 Statement 4. Pre-viewing English lessons helps me understand subjects well

\begin{tabular}{cccccc}
\hline & & Frequency & Percent & Valid Percent & Cumulative Percent \\
\hline \multirow{3}{*}{ Valid } & neutral & 2 & 12.5 & 12.5 & 12.5 \\
\cline { 2 - 6 } & agree & 7 & 43.8 & 43.8 & 56.3 \\
\cline { 2 - 6 } & strongly agree & 7 & 43.8 & 43.8 & 100.0 \\
\cline { 2 - 6 } & Total & 16 & 100.0 & 100.0 & \\
\hline
\end{tabular}

Table 8 Statement 5. I find it easy to answer the exercises in class when I study them by the flipped classroom strategy.

\begin{tabular}{|c|c|c|c|c|c|}
\hline & & Frequency & Percent & Valid Percent & Cumulative Percent \\
\hline \multirow[t]{3}{*}{ Valid } & agree & 11 & 68.8 & 68.8 & 68.8 \\
\hline & strongly agree & 5 & 31.3 & 31.3 & 100.0 \\
\hline & Total & 16 & 100.0 & 100.0 & \\
\hline
\end{tabular}

Statement 6 evaluated if students had positive attitudes towards the flipped classroom strategy over the traditional way of learning. (37.5\%) of students' responses agreed that the flipped classroom method was more engaging than the traditional teaching, while the rest were an equal percentage (31.3\%) neutral and strongly agree (mode=4). (See table 9)

Table 9 Statement 6. The flipped classroom is more engaging than traditional classroom instruction.

\begin{tabular}{llcccc}
\hline \multirow{2}{*}{ Valid } & & Frequency & Percent & $\begin{array}{c}\text { Valid } \\
\text { Percent }\end{array}$ & $\begin{array}{c}\text { Cumulative } \\
\text { Percent }\end{array}$ \\
\cline { 2 - 6 } & neutral & 5 & 31.3 & 31.3 & 31.3 \\
\cline { 2 - 6 } & agree & 6 & 37.5 & 37.5 & 68.8 \\
\hline $\begin{array}{l}\text { strongly } \\
\text { agree }\end{array}$ & 5 & 31.3 & 31.3 & 100.0 \\
\cline { 2 - 6 } & Total & 16 & 100.0 & 100.0 & \\
\hline
\end{tabular}

In the statement 7 students were asked to evaluate whether the flipped classroom gave them greater opportunities to communicate with the teacher and other students. Students' responses showed that they agreed that the flipped classroom strategy enhanced their 
communication with the teacher and the classmates during the lessons (mode $=4$ ). (See table 10)

Table 10 Statement 7. The flipped classroom gives me greater opportunities to communicate with the teacher and other students.

\begin{tabular}{|c|c|c|c|c|c|}
\hline & & Frequency & Percent & $\begin{array}{l}\text { Valid } \\
\text { Percent }\end{array}$ & $\begin{array}{c}\text { Cumulative } \\
\text { Percent }\end{array}$ \\
\hline \multirow[t]{4}{*}{ Valid } & neutral & 3 & 18.8 & 18.8 & 18.8 \\
\hline & agree & 8 & 50.0 & 50.0 & 68.8 \\
\hline & $\begin{array}{c}\text { strongly } \\
\text { agree }\end{array}$ & 5 & 31.3 & 31.3 & 100.0 \\
\hline & Total & 16 & 100.0 & 100.0 & \\
\hline
\end{tabular}

Statements 8 and 9 evaluated whether the availability of watching video lessons many times and at any time helped the students to understand well. Responses indicated that students strongly agree that they comprehend the lessons well by watching videos more than once $(\operatorname{mode}=4)$ and they were more comforted by revising and watching videos at any time they want (mode=5). (See tables 11, 12)

Table 11 Statement 8 . The possibility of re-watching the video lesson more than once helps me to understand well

\begin{tabular}{llcccc}
\hline \multirow{2}{*}{ Valid } & & Frequency & Percent & $\begin{array}{c}\text { Valid } \\
\text { Percent }\end{array}$ & $\begin{array}{c}\text { Cumulative } \\
\text { Percent }\end{array}$ \\
\cline { 2 - 6 } & neutral & 2 & 12.5 & 12.5 & 12.5 \\
\cline { 2 - 6 } & agree & 7 & 43.8 & 43.8 & 56.3 \\
\cline { 2 - 6 } & strongly agree & 7 & 43.8 & 43.8 & 100.0 \\
\cline { 2 - 6 } & Total & 16 & 100.0 & 100.0 & \\
\hline
\end{tabular}

Table 12 Statement 9. The flipped classroom strategy allows me the opportunity to study and revise the lessons at any time I want.

\begin{tabular}{clc|c|c|c}
\hline & & Frequency & Percent & $\begin{array}{c}\text { Valid } \\
\text { Percent }\end{array}$ & $\begin{array}{c}\text { Cumulative } \\
\text { Percent }\end{array}$ \\
\hline \multirow{3}{*}{ Valid } & neutral & 1 & 6.3 & 6.3 & 6.3 \\
\cline { 2 - 6 } & agree & 7 & 43.8 & 43.8 & 50.0 \\
\cline { 2 - 6 } & strongly agree & 8 & 50.0 & 50.0 & 100.0 \\
\cline { 2 - 6 } & Total & 16 & 100.0 & 100.0 & \\
\hline
\end{tabular}

Statements 10 and 11explored whether the flipped classroom helped to improve students' language skills. Responses indicated that students felt their reading, speaking, writing, listening as well as language grammar were enhanced (68.8\%). (See tables 13, 14)

Table 13 Statement 10. The Flipped Classroom helps me to learn English language skills (writing, reading, listening, speaking)

\begin{tabular}{llcccc}
\hline \multirow{2}{*}{ Valid } & & & & Valid & Cumulative \\
Prequency & Percent & Percent & Percent \\
\cline { 2 - 6 } & disagree & 1 & 6.3 & 6.3 & 6.3 \\
\cline { 2 - 6 } & neutral & 3 & 18.8 & 18.8 & 25.0 \\
\cline { 2 - 6 } & agree & 8 & 50.0 & 50.0 & 75.0 \\
\cline { 2 - 6 } & strongly agree & 4 & 25.0 & 25.0 & 100.0 \\
\cline { 2 - 6 } & Total & 16 & 100.0 & 100.0 & \\
\hline
\end{tabular}


Table 14 Statement 11. The flipped classroom helps me understand English grammar well

\begin{tabular}{llcccc}
\hline \multirow{2}{*}{ Valid } & & Frequency & Percent & $\begin{array}{c}\text { Valid } \\
\text { Percent }\end{array}$ & $\begin{array}{c}\text { Cumulative } \\
\text { Percent }\end{array}$ \\
\cline { 2 - 6 } & neutral & 2 & 12.5 & 12.5 & 12.5 \\
\cline { 2 - 6 } & agree & 11 & 68.8 & 68.8 & 81.3 \\
\cline { 2 - 6 } & strongly agree & 3 & 18.8 & 18.8 & 100.0 \\
\cline { 2 - 6 } & Total & 16 & 100.0 & 100.0 & \\
\hline
\end{tabular}

Regarding students' autonomous learning, students were asked in statements 12 and 13 if the strategy of the flipped classroom encouraged them to work on their own for selflearning. Results indicated that students strongly agreed that flipped classroom helped them to be autonomous. (See tables 15, 16)

Table 15 Statement 12. The flipped instruction Develops my ability to think and selflearning.

\begin{tabular}{cccccc}
\hline \multirow{7}{*}{ Valid } & & & & Valid & \\
& & Frequency & Percent & Percent & Cumulative Percent \\
\cline { 2 - 6 } & neutral & 4 & 25.0 & 25.0 & 25.0 \\
\cline { 2 - 6 } & agree & 8 & 50.0 & 50.0 & 75.0 \\
\cline { 2 - 6 } & strongly agree & 4 & 25.0 & 25.0 & 100.0 \\
\cline { 2 - 6 } & Total & 16 & 100.0 & 100.0 & \\
\hline
\end{tabular}

Table 16 Statement 13. The flipped classroom method allows me the opportunity to self-learning.

\begin{tabular}{llcccc}
\hline \multirow{2}{*}{ Valid } & & Frequency & Percent & $\begin{array}{c}\text { Valid } \\
\text { Percent }\end{array}$ & $\begin{array}{c}\text { Cumulative } \\
\text { Percent }\end{array}$ \\
\cline { 2 - 6 } & neutral & 2 & 12.5 & 12.5 & 12.5 \\
\cline { 2 - 6 } & agree & 10 & 62.5 & 62.5 & 75.0 \\
\cline { 2 - 6 } & strongly agree & 4 & 25.0 & 25.0 & 100.0 \\
\cline { 2 - 6 } & Total & 16 & 100.0 & 100.0 & \\
\hline
\end{tabular}

In statement 14 students asked to evaluate whether they preferred all subjects to be taught using the flipped classroom strategy. Students' responses showed that the majority strongly agreed and agreed while only (12.5\%) disagreed. This result indicates that the flipped classroom method effects the students positively. (See table 17)

Table 17 Statement 14. I prefer all subjects to be taught using the flipped classroom method.

\begin{tabular}{cccccc}
\hline \multirow{7}{*}{ Valid } & & Frequency & Percent & $\begin{array}{c}\text { Valid } \\
\text { Percent }\end{array}$ & $\begin{array}{c}\text { Cumulative } \\
\text { Percent }\end{array}$ \\
\cline { 2 - 6 } & disagree & 2 & 12.5 & 12.5 & 12.5 \\
\cline { 2 - 6 } & neutral & 3 & 18.8 & 18.8 & 31.3 \\
\cline { 2 - 6 } & agree & 5 & 31.3 & 31.3 & 62.5 \\
\cline { 2 - 6 } & strongly agree & 6 & 37.5 & 37.5 & 100.0 \\
\cline { 2 - 6 } & Total & 16 & 100.0 & 100.0 & \\
\hline
\end{tabular}


The final statement evaluated whether the flipped classroom allowed the students to deal with the technology. Results showed that the flipped strategy helped the students and allowed them to deal with the technology. (See table 18)

Table 18 Statement 15. The flipped classroom strategy allows me the opportunity to deal with technology.

\begin{tabular}{cccccc}
\hline & & & & Valid & Cumulative \\
& & Frequency & Percent & Percent & Percent \\
\hline Valid & Neutral & 3 & 18.8 & 18.8 & 18.8 \\
\cline { 2 - 6 } & Agree & 6 & 37.5 & 37.5 & 56.3 \\
\cline { 2 - 6 } & strongly agree & 7 & 43.8 & 43.8 & 100.0 \\
\cline { 2 - 6 } & Total & 16 & 100.0 & 100.0 & \\
\hline
\end{tabular}

\section{Discussion}

The current study aimed to investigate whether the flipped classroom model would make a significant difference in the experimental group's achievements in regard to English language learning among the Libyan college students. The post-test results showed that a difference was found to be statistically significant for the experimental group and applying the flipped classroom strategy seemed to play a significant role in enhancing students' English language knowledge, since the experimental group mean score was higher than the mean score of the control group. This result compatible with the findings of studies in other educational and cultural contexts such as Ahmad (2016), Karimi and Hamzavi, (2017), AlHarbi and Alshumaimeri, (2016) and Basal, A. (2015), whose studies revealed that the flipped method had a positive impact on students' language skills ability as well as many benefits in terms of saving of class time, learning at one's own pace and students' participation in the class.

In contrast to the outcomes of traditional teaching methods i.e. Grammar Translation Method applied in Libyan schools and universities that caused students to be passive and depend on the teacher to lead them in class, the flipped classroom strategy, according to the results of this study, made students active learners and participate effectively by giving them a chance to learn autonomously and work collaboratively.

In addition, the results of this study indicated that using flipped classroom strategy could help Libyan students solve the problem stated by (Elabbar, 2011, Khalid, 2017, Sawani, 2009, Reza et al., 2007) regarding the lack of communicative competent and shortcomings in communication skills in real life since the flipped strategy offered them watching and learning from real videos of communication of native speakers.

Furthermore, the results of analysing students' responses to the questionnaire and their opinions and attitudes towards flipped classroom strategy revealed that students were positive and liked the instructions of the flipped classroom model, also they agreed that other courses would be taught in this way. These results aligned with other studies findings such as AlHarbi and Alshumaimeri, (2016), Karimi and Hamzavi, (2017), Ahmed (2016), Obari \& Lambacher, (2015) in that attitudes of students towards the flipped classroom strategy were generally positive. 
In summary, it was clear from the findings of this study that the teaching of English to Libyan college students could be improved and led to positive effects if teachers adopt the flipped classroom model in their teaching neglecting the traditional teaching methods they use since the study proved the possibility of applying the flipped classroom method in the Libyan context.

\section{Conclusion and Recommendations}

\subsection{Conclusion}

The findings of the study showed that the teaching strategy of the flipped classroom helped students to improve their English. It encouraged them to be independent learners, highly responsible for their own learning (autonomous learners), yet it improved relationship between teacher and students. Based on the questionnaire results, learners had positive thought on Flipped Classroom to improve their English. Indeed, they thought that this model could help them to enhance their English. The results could be useful as an English teaching technique to improve Libyan university students' achievement in learning English. The results of the present study provided concepts of teaching and learning with technology to Libyan teachers and learners.

\subsection{Recommendations}

Through the findings of the study, the following recommendations can be drawn:

1- Since the flipped classroom strategy is a new concept, it is recommended to prepare training programs to introduce teachers and students to what is flipped classroom strategy and its positive benefits.

2- Holding workshops for EFL teachers and students to train on how to apply the concept of flipped learning strategy before implementation.

3- Encouraging teachers to use modern techniques in their teaching, as this has a positive impact on the development of students' attitudes towards using this type of technology and benefiting from it in their real life.

4 - Encourage EFL teachers to use the strategy of flipped classroom instead of traditional teaching.

5- More research is needed to investigate the effectiveness of the flipped classroom in developing different language skills.

6- Conduct similar studies in different disciplines.

7- Conduct further studies on the effect of using the flipped classroom strategy in other faculties of the university. 


\section{References}

Abukhattala, I., (2016) The Use of Technology in Language Classrooms in Libya. International Journal of Social Science and Humanity, 6(4),262-267.

Ahmed, M. A. A. S., (2016) The Effect of a Flipping Classroom on Writing Skill in English as a Foreign Language and Students' Attitude Towards Flipping. US-China Foreign Language, 14 (2) 98-114

Ahmed, S. Z., (2016) The Flipped Classroom Model to Develop Egyptian EFL Students' Listening Comprehension. English Language Teaching, 9 (9) 166-178.

Al-Harbi, S., \& Alshumaimeri, Y. (2016). The flipped classroom impact in grammar class on EFL Saudi secondary school students' performances and attitudes. English Language Teaching, 9(10), 60-80.

Aloreibi, A, \& Carey, M. D.(2016). English language teaching in Libya after Gaddafi. Springer International Publishing.

Basal, A. (2015). The Implementation of a Flipped Classroom in Foreign Language Teaching. Turkish online Journal of Distance Education-TOJDE.16(4),28-37

Du, S., Fu, Z. \& Wang, Y. (2014). The Flipped Classroom-Advantages and Challenges. International Conference on Economic Management and Trade Cooperation 17-20. doi:10.2991/emtc-14.2014.3

Elabbar, A. A. (2011). An investigation of influences affecting Libyan English as foreign language university teachers' (LEFLUTS), teaching approaches in the language classrooms. Doctoral dissertation, University of Glasgow.

El-Bassuony, J., M., (2016) The effectiveness of Flipped Learning in Developing English Grammatical Performance of Underachieving Language Learning at the Secondary Stage. International Journal of English Language Teaching, 4(8), 76-102.

Farah, M. (2014). The Impact of Using a Flipped Classroom Instruction on the Writing Performance of Twelfth Grade Female Emirati Students in the Applied Technology High School (ATHS). Master thesis. The British University, Dubai.

Hung, H. (2015). Flipping the classroom for English language learners to foster active learning. Computer Assisted Language Learning, 28(1), 81-96.

Karimi, M. \& Hamzavi, R. (2017) The Effect of Flipped Model of Instruction on EFL Learners' Reading Comprehension: Learners' Attitudes in Focus. Advances in Language and Literary Studies, 8 (1) 95-103.

Khalid, K. A. A., (2017) Learning and Teaching in English: A Case Study of Higher Education in Libya. Doctoral thesis, Liverpool John Moores University. Retrieved from:

http://researchonline.ljmu.ac.uk/6757/1/M\%3A\%5CMyThesis\%5C2017khalidphd.pdf

Lo, K. C., \&Hew, F. K. (2017) A critical review of flipped classroom challenges in K-12 education: possible solutions and recommendations for future research. Research and Practice in Technology Enhanced Learning, 12(4) 1-22. Retrieved from: https://telrp.springeropen.com/articles/10.1186/s41039-016-0044-2

Milman, N. (2012) The flipped classroom strategy: What is it and how can it be used? Distance Learning, 9 (3), 85-87. 
Obari, H., \& Lambacher, S. (2015). Successful EFL teaching using mobile technologies in a flipped classroom. In F. Helm, L. Bradley, M. Guarda, \& S. Thouësny (Eds.), Critical CALL - Proceedings of the 2015 EUROCALL Conference, Padova, Italy (pp.433-438). Dublin: Research-publishing.net

Orafi, S. M. S., \& Borg, S. (2009). Intentions and Realities in Implementing Communicative Curriculum Reform. System, 37(2), 243-253.

Rajendran, S. (2010). ELT in Libyan universities-a pragmatic approach. Language in India, 9(63). Retrieved from: http://languageinindia.com/sep2010/v10i9sep2010.pdf\#page $=66$

Reza Arabsheibani, G. and L. Manfor (2007) Non-Linearities in Returns to Education in Libya. Education Economics 9(1), 134-145.

Sawani, F. (2009) Factors affecting English teaching and its materials preparation in Libya. Unpublished $\mathrm{PhD}$ Thesis, University of Essex.

Wallace, A. (2014). Social Learning Platforms and the Flipped Classroom. International Journal of Information and Education Technology, 4(4), 293-296. http://dx.doi.org/10.1109/ICeLeTE.2013.6644373 


\section{Appendix (A) The Placement Test}

\section{Choose the correct answers}

\begin{tabular}{|c|c|c|c|}
\hline 1 & $\begin{array}{l}\text { Tom lives next door. } \\
\text { guy. A) She } \begin{array}{lll}\text { B) It } & \text { C) } \mathrm{He} & \text { D) His }\end{array}\end{array}$ & 21 & $\begin{array}{l}\text { I ... this film many times. } \\
\begin{array}{lll}\text { B) saw s) seen } & \text { C) sees } & \text { D) have seen }\end{array}\end{array}$ \\
\hline 2 & $\begin{array}{l}\text { Brutus is ........ honorable man. } \\
\begin{array}{llll}\text { A) a } & \text { B) an } & \text { C) } x & \text { D) he }\end{array}\end{array}$ & 22 & $\begin{array}{l}\text { I shall be there } \ldots \ldots \ldots \ldots .4 \text { o' clock. } \\
\begin{array}{llll}\text { A) at } & \text { B) in } & \text { C) on } & \text { D) of }\end{array}\end{array}$ \\
\hline 3 & $\begin{array}{llll}\text { What......... they do? } & \text { A) did } \\
\text { B) have } & \text { C) do } & \text { D) does } & \end{array}$ & 23 & 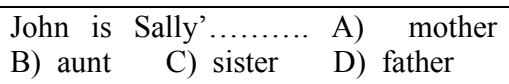 \\
\hline 4 & $\begin{array}{l}\text { Teachers do noble work. We must } \\
\text { respect ......A) his } \\
\begin{array}{llr}\text { D) they } & & \text { C) them }\end{array}\end{array}$ & 24 & 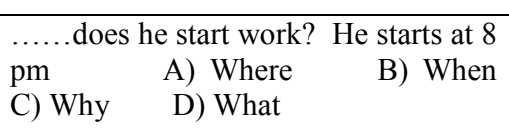 \\
\hline 5 & $\begin{array}{l}\text { Phone me ........ lunch time. } \\
\begin{array}{llll}\text { A) at } & \text { B) in } & \text { C) on } & \text { D) of }\end{array}\end{array}$ & 25 & $\begin{array}{l}\text { They } \ldots \ldots \ldots \text { here three hours ago. } \\
\begin{array}{llll}\text { A) reach } & \text { B) reached } & \text { C) } \\
\text { reaches } & \text { D) is reaching } & \end{array}\end{array}$ \\
\hline 6 & $\begin{array}{l}\text { I went to ........ hospital to see Jane. } \\
\begin{array}{llll}\text { A) a } & \text { B) an } & \text { C) the } & \text { D) } x\end{array}\end{array}$ & 26 & $\begin{array}{l}\text { Lidia ....... in London since } 1990 . \\
\begin{array}{llll}\text { A) lives } & \text { B) have lived } & \text { C) has } \\
\text { lived } & \text { D) live } & \end{array}\end{array}$ \\
\hline 7 & $\begin{array}{l}\text { How ....... does it cost? } \\
\begin{array}{lll}\text { A) many } & \text { B) far } & \text { C) old } \\
\text { D) much } & & \end{array}\end{array}$ & 27 & 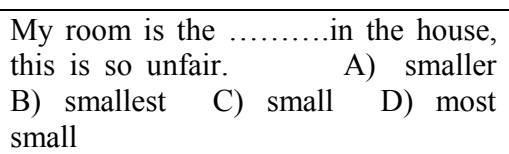 \\
\hline 8 & $\begin{array}{l}\text { The horse fell down and broke ........ } \\
\text { leg. } \\
\begin{array}{llll}\text { A) her } & \text { B) It } & \text { C) he } & \text { D) its }\end{array}\end{array}$ & 28 & $\begin{array}{l}\text { How ....... students are there in your } \\
\text { class? } \\
\begin{array}{lll}\text { C) old } & \text { D) much } & \text { B) many } \\
\text { C) } & \end{array}\end{array}$ \\
\hline 9 & $\begin{array}{l}\text { Where ......... Sara from? } \\
\begin{array}{llll}\text { A) does } & \text { B) has } & \text { C) do } & \text { D) is }\end{array}\end{array}$ & 29 & $\begin{array}{l}\text { Do you like..........? Yes, of course } \\
\text { I like you. A) her } \\
\begin{array}{lll}\text { D) them } & & \end{array}\end{array}$ \\
\hline 10 & $\begin{array}{lll}\text { My grandparents always } & . \ldots \ldots \ldots \text { lots } \\
\text { of pets. } & \text { A) keeps } & \text { B) kept } \\
\text { C) keep } & \text { D) is keeping } & \end{array}$ & 30 & $\begin{array}{l}\text { Running is............. } \\
\begin{array}{lll}\text { A) tired } & \text { B) bored } & \text { C) excited } \\
\text { D) tiring } & & \end{array}\end{array}$ \\
\hline 11 & $\begin{array}{l}\text { Istanbul is beautiful } \ldots \ldots \ldots \ldots \ldots \\
\text { Spring } \\
\begin{array}{llll}\text { A) at } & \text { B) in } & \text { C) on } & \text { D) of }\end{array}\end{array}$ & 31 & $\begin{array}{l}\text { The sun.........in the east. } \\
\begin{array}{lll}\text { A) rose } & \text { B) rise } & \text { C) is rising } \\
\text { D) rises } & & \end{array}\end{array}$ \\
\hline 12 & $\begin{array}{l}\text { The elephant is a big animal. ........ can } \\
\text { weigh up to ten tons. } \\
\begin{array}{llll}\text { A) They } & \text { B) It } & \text { C) He } & \text { D) She }\end{array}\end{array}$ & 32 & $\begin{array}{l}\text { Is she married? } \\
\begin{array}{ll}\text { A) Yes, he is } & \text { B) No, she is } \\
\text { C) Yes, she is } & \text { D) Yes, she isn't }\end{array}\end{array}$ \\
\hline 13 & $\begin{array}{l}\text { Did you ........ shopping yesterday? } \\
\begin{array}{lll}\text { A) went } & \text { B) gone } & \text { C) go } \\
\text { D) goed } & & \end{array}\end{array}$ & 33 & $\begin{array}{l}\text { He ....... his father at the moment. } \\
\begin{array}{lll}\text { A) helps } & \text { B) help } & \text { C) helped } \\
\text { D) is helping } & & \end{array}\end{array}$ \\
\hline 14 & $\begin{array}{l}\text { Can you speak English? } \\
\begin{array}{ll}\text { A) Yes, I am } & \text { B) No, I can't } \\
\text { C) Yes, I do } & \text { D) Yes, he can }\end{array}\end{array}$ & 34 & $\begin{array}{l}\text { What time it? It is ..........(6:32) } \\
\begin{array}{lll}\text { A) twenty eight to seven } \quad \text { B) thirty } \\
\text { two past six } & \text { C) thirty two to six } \\
\text { D) six thirty } & \end{array}\end{array}$ \\
\hline 15 & Sam, John and Richard are students. & 35 & Does he work hard? \\
\hline
\end{tabular}




\begin{tabular}{|c|c|c|c|}
\hline & $\begin{array}{l}\text { A) They } \begin{array}{lll}\text { B) It } & \text { C) Their } & \text { D) Them }\end{array}\end{array}$ & & $\begin{array}{l}\text { A) Yes, he doesn't } \quad \text { B) No, does } \\
\begin{array}{ll}\text { C) Yes, he is } & \text { D) Yes, he does }\end{array}\end{array}$ \\
\hline 16 & $\begin{array}{l}\text { Rebecca and Lisa are .......... } \\
\begin{array}{llll}\text { A) brother } & \text { B) sister } & \text { C) uncles } \\
\text { D) sisters } & & & \end{array}\end{array}$ & 36 & $\begin{array}{l}\text { We ........ play this game with you. } \\
\begin{array}{lll}\text { A) won't } & \text { B) didn't } & \text { C) aren't } \\
\text { D) are } & & \end{array}\end{array}$ \\
\hline 17 & $\begin{array}{l}\text { Look, there are dark clouds, it } \ldots \ldots \\
\text { rain. } \\
\begin{array}{llll}\text { A) will } & \text { B) is going to } & \text { C) does } & \text { D) } \\
\text { did }\end{array}\end{array}$ & 37 & $\begin{array}{l}\text { Judy had an .............holiday. } \\
\begin{array}{ll}\text { A) interesting } & \text { B) interested } \\
\text { C) bored } & \text { D) boring }\end{array}\end{array}$ \\
\hline 18 & $\begin{array}{l}\text { My kids..... play chess very well. A) } \\
\begin{array}{llll}\text { doesn't } & \text { B) didn't } & \text { C) aren't } & \text { D) } \\
\text { don't } & & & \end{array}\end{array}$ & 38 & $\begin{array}{l}\text { He broke the news to her........ } \\
\begin{array}{lll}\text { A) gently } & \text { B) gentle } & \text { C) slow } \\
\text { D) quick } & & \end{array}\end{array}$ \\
\hline 19 & 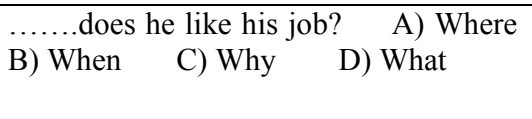 & 39 & $\begin{array}{l}\text { We haven't planted } \ldots . . . \ldots \text { roses in } \\
\text { the garden. A) any } \\
\begin{array}{ll}\text { D) a some s) an } \\
\end{array}\end{array}$ \\
\hline 20 & $\begin{array}{l}\text { Titanic was ..........successful film of } \\
\text { the year. A) most } \\
\begin{array}{lll}\text { more more } & \text { C) the most }\end{array}\end{array}$ & 40 & $\begin{array}{l}\text { Mark is ......... than Kathy } \\
\begin{array}{llll}\text { A) tallest } & \text { B) more tall } & \text { C) taller } \\
\text { D) tall } & & & \end{array}\end{array}$ \\
\hline
\end{tabular}




\section{Appendix (B) The Post-test}

\section{Answer all the following questions}

Total Marks: 40

4 Marks

Q.1. Read the text and answer the following questions:

Making Friends with Pizza

Roger is new in town, and it has been hard to make friends. The kids at school are nice, but Roger is shy. His birthday is coming up soon. He is planning a big party. It will be a lot of fun. There will be cake, ice cream, and a treasure hunt. But what if none of the other kids want to come?

One week before his party, Roger and his dad go to their favorite restaurant. Benny's Pizza Parlor makes the best pizza in town. Roger orders a large pie, with four kinds of cheese and extra pepperoni. He loves every bite. When he is finished, Roger and his dad go to the kitchen to talk to Benny.

1-Why has it been hard for Roger to make friends?

2-What is Roger planning to make?

3-What will be there in the party?

4-Where do Roger and his dad go before his party?

Q.2. Complete by using appropriate (subject/object) pronouns.

4 Marks

1. Mike lives next door. is a handsome guy.

2. My grandmother bought .......... a beautiful necklace for my birthday. is very expensive.

3. Teachers do noble work. We must respect

4. Alice was not a bit hurt and ............... jumped up on to feet in a moment

5. The cow fell down and broke ............... leg.

6 . The elephant is the biggest land animal. ............ can weigh up to ten tons.

Q-3- Answer the following questions.

4 Marks

1. Where are you from?

2. How old are you?

3. What is your job?

4. Are you married?

Q.4. Choose the correct form of the verb given in the brackets.

4 Marks

1. They $\ldots \ldots \ldots \ldots \ldots \ldots \ldots \ldots \ldots \ldots \ldots$ (reach) here three hours ago.

2. John ................... his mother every Friday. (visited - visit - visits)

3. She ..................... swimming last week. (go-went - goes )

4. He ............................ (help) his father at the moment.

5 . It usually ............................ (rain) in winter.

6. I .......................... (go) shopping yesterday.

7. My mother .............. the house daily. (cleaned-cleans - has cleaned)

8 . The sun $\ldots \ldots \ldots \ldots \ldots \ldots \ldots \ldots \ldots \ldots \ldots$ (rise) in the east.

Q.5. Change the following sentences into negative.

4 Marks

1. James managed to arrive on time.

2. He goes to office at 9 o'clock.

https://misuratau.edu.ly/journal/arts 
3. He can speak French.

4. The milkman will come early tomorrow.

\begin{tabular}{|c|c|c|}
\hline Q-6- Match: & & 3 Marks \\
\hline "1-Where .............? & A- At nine o'clock. & \\
\hline 2-What ..............? & B- quickly & \\
\hline 3-When.............? & C- In Italy & \\
\hline 4-Who ..............? & D- Because he does not have a car. & \\
\hline 5 -Why ..............? & $\mathrm{E}-\mathrm{He}$ is a police man & \\
\hline 6-How...............?? & F- Tom & \\
\hline
\end{tabular}
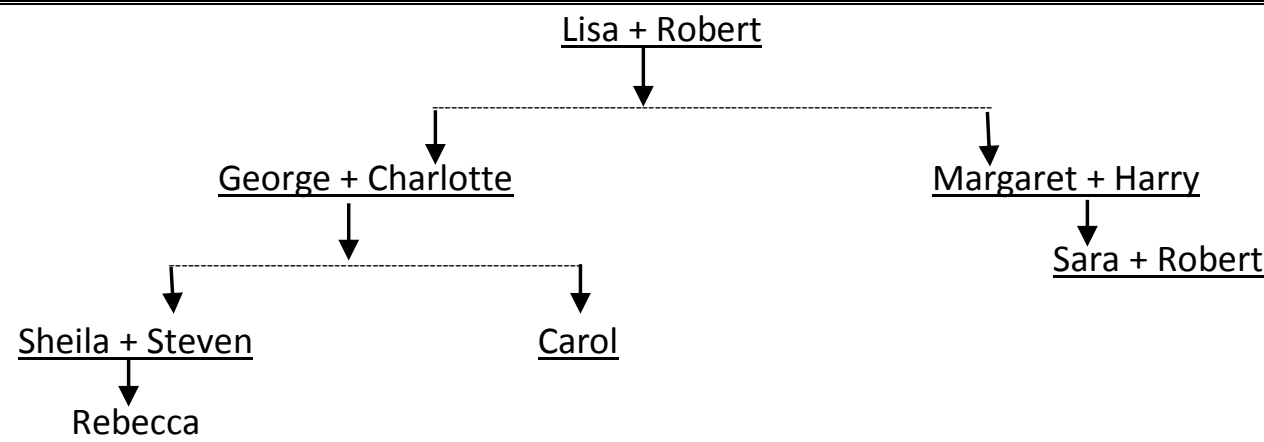

[grandfather, father, mother, son, daughter, grandson, aunt, uncle, cousin, nephew, niece, parents, children, husband, wife, brother, sister]

1. Sheila and Steven are Rebecca's

2. ................................is George and Charlotte's daughter.

3. Lisa is Carol's

4. Margaret and are sisters.

5. Margaret is Harry's

6. Sara is Margaret's

7. Steven is Margaret's

8. Steven is Sheila's

Q.8. What is the time?

3 Marks

1) $10: 20=$

2) $2: 32=$

3) $1: 58=$

Q.9. Complete by using an appropriate article. ( a - an - the - X)

4 Marks

1. I learnt French at home.

2. Brutus is nice man.

3. She told me interesting story.

4. Sara is beautiful girl.

5. I went to ...................... hospital to see Jane.

6. He never leaves his home without ..................... umbrella.

7. She is..... my best friend.

8. Chinese is ....................... most difficult language to learn.

Q.10. Choose the correct preposition.

4 Marks
1. The thief was arrested
.... the police.
a) on
b) by
c) at
2. My birthday is May 26th.
a) on
b) in
c) at 
3. Call him Friday.

a) at

b) in

c) on

4. Phone me night.

a) at

b) in

c) on

5 . I shall be there .. 4 o' clock

a) at b) on

c) in

6 . They will get married Summer.

a) at b) in

c) on

7. We shall be ready a few minutes.

a) on

b) in

c) at

8. He brought the letter the morning.

a) at

b) on

c) in

Q.11. Write two sentences about things you are doing now.

2 Marks

Good Luck for you all 


\section{Appendix (C) The Questionnaire}

\section{Students' perceptions about using Flipped Classroom}

Please rate the following items on the scale provided to indicate your agreement:

\begin{tabular}{|c|c|c|c|c|c|c|}
\hline No & Item & $\begin{array}{l}\text { Strongly } \\
\text { agree }\end{array}$ & Agree & Neutral & Disagree & $\begin{array}{l}\text { Strongly } \\
\text { disagree }\end{array}$ \\
\hline 1 & I feel comfortable in English language lessons & & & & & \\
\hline 2 & $\begin{array}{l}\text { Teaching English by using Flipped Classroom } \\
\text { strategy gives rise to activity }\end{array}$ & & & & & \\
\hline 3 & $\begin{array}{l}\text { I enjoy learning English when the lesson is } \\
\text { presented as a video }\end{array}$ & & & & & \\
\hline 4 & $\begin{array}{l}\text { Pre-viewing English lessons } \\
\text { understand subjects well }\end{array}$ & & & & & \\
\hline 5 & $\begin{array}{l}\text { I find it easy to answer the exercises in class } \\
\text { when I study them by the flipped classroom } \\
\text { strategy. }\end{array}$ & & & & & \\
\hline 6 & $\begin{array}{l}\text { The flipped classroom is more engaging than } \\
\text { traditional classroom instruction. }\end{array}$ & & & & & \\
\hline 7 & $\begin{array}{l}\text { The flipped classroom gives me greater } \\
\text { opportunities to communicate with the teacher } \\
\text { and other students. }\end{array}$ & & & & & \\
\hline 8 & $\begin{array}{l}\text { The possibility of re-watching the video lesson } \\
\text { more than once helps me to understand well }\end{array}$ & & & & & \\
\hline 9 & $\begin{array}{l}\text { The flipped classroom strategy allows me the } \\
\text { opportunity to study and revise the lessons at } \\
\text { any time I want. }\end{array}$ & & & & & \\
\hline 10 & $\begin{array}{l}\text { The Flipped Classroom helps me to learn } \\
\text { English language skills (writing, reading, } \\
\text { listening, speaking) }\end{array}$ & & & & & \\
\hline 11 & $\begin{array}{l}\text { The flipped classroom helps me understand } \\
\text { English grammar well }\end{array}$ & & & & & \\
\hline 12 & $\begin{array}{l}\text { The flipped instruction Develops my ability to } \\
\text { think and self-learning. }\end{array}$ & & & & & \\
\hline 13 & $\begin{array}{l}\text { The flipped classroom method allows me the } \\
\text { opportunity to self-learning. }\end{array}$ & & & & & \\
\hline 14 & $\begin{array}{l}\text { I prefer all subjects to be taught using the } \\
\text { flipped classroom method. }\end{array}$ & & & & & \\
\hline 15 & $\begin{array}{l}\text { The flipped classroom strategy allows me the } \\
\text { opportunity to deal with technology. }\end{array}$ & & & & & \\
\hline
\end{tabular}

